\title{
The extent of use of basic Facebook user-generated content by the national tourism organizations in Europe
}

\author{
Uglješa Stankov ${ }^{1^{*}}$, Lazar Lazić ${ }^{1}$ and Vanja Dragićević ${ }^{1}$
}

Received: 13/09/2009 Accepted : 05/04/2010

\begin{abstract}
${ }^{1}$ University of Novi Sad, Faculty of Sciences, Department of Geography, Tourism and Hotel Management Postal address: Trg Dositeja Obradovića 3, 21000 Novi Sad, Serbia; tel: +381-21-450602; fax: +381-21-450602 *Corresponding author; e-mail: ugljesa.stankov@dgt.uns.ac.rs
\end{abstract}

\begin{abstract}
The social networking sites or the social media have enormous number of users. Currently, Facebook is the most used social media on the Internet and is among the most popular websites in Europe and worldwide. National tourism organizations in Europe should capitalize on those facts, especially using Facebook user-generated content. Facebook offers many ways for tourism promotion using features like Pages and Groups. The purpose of this paper is to identify how many NTOs in Europe have an official presence on Facebook and to determine the extent of the use of basic Facebook user-generated content (Pages and Groups). The research results showed that about half of NTOs do not have an official presence on Facebook, almost one-third of them have Facebook Pages, and almost a fifth of them have a Group. Besides the insignificant Facebook presence, NTOs do not use all the advantages that are offered by user-generated content. All trends show that Facebook community will continue to grow. NTOs should consider using Facebook in the next couple of years, as an effective marketing strategy.
\end{abstract}

(C) 2010 International University College. All rights reserved

Keywords: Facebook, user-generated content, NTOs, Europe

Citation: Stankov U., L. Lazić, V. Dragićević (2010) The extent of use of basic Facebook usergenerated content by the national tourism organizations in Europe. European Journal of Tourism Research 3(2), pp. 105-113

\section{Introduction}

Millions of computer users worldwide have begun exploring the Internet and have joined one or more on-line communities that have sprung up to serve consumer needs for communication, information, and entertainment (Wang, Yu, \& Fesenmaier, 2002). People have begun using social networking sites to connect to others in a wide variety of ways, including dating, meeting others with common interests, sharing information. Chung \& Buhalis (2009) RESEARCH PAPER point out that users participate in virtual travel communities for a wide range of purposes, which may include fun, companionship, and demonstration of expertise, enjoyment, and amusement as an end in itself. Social networking has made it simple to develop relations that transcend age, race, culture and geographical differences (Graham, Faix, \& Hartman, 2009).

In the past couple years Facebook is one of the 
most visited websites in the world, and the most visited social networking website (White, 2009). In April 2009, Facebook announced that it had reached 200 million members, and barely over three months later, in July the number of members rose to 250 million (McEntegart, 2009). As Facebook has increasingly focused its attention on global expansion and increased penetration across countries and regions, the site has catapulted to the six ranked web property worldwide with 275 million visitors in February 2009 , a $175 \%$ increase versus a year ago. One of the global regions that best shows its growth is Europe, where the site has seen a $314 \%$ increase to nearly 100 million visitors (Anon, 2009a). At the same time, nearly $60 \%$ of European on-line consumers are involved in social computing (Kemp, 2007). Facebook use is $4.1 \%$ of all minutes spent on-line in Europe. Facebook also accounts for a full $30.4 \%$ of minutes spent in the social networking category (Anon, 2009a).

These facts cannot be ignored by national tourism organizations (NTOs) which have an important role in creating awareness among international and national markets. Different travel and tourism organizations are beginning to realize the importance of using the power of on-line communities (Wang \& Fesenmaier, 2003). Using the power of social media, NTOs are encouraging residents, local businesses, visitors and third-party suppliers to tell the destination's story. NTOs can create and sponsor their own pages, groups, pay for advertisements, run polls, create applications that users can include on their own pages.

Despite the growing popularity of Facebook and it currently being the most influential social medium in the world, there are no significant studies that had examined the use of Facebook by NTOs. In travel and tourism, past research has focused attention on the sociopsychological aspects of social media use (Illum, Ivanov, \& Liang, 2009). Therefore, this paper fills the gap by presenting research on the extent of use of Facebook by NTOs. The focus of this paper is on Facebook Pages and Groups, which represent user-generated content (UGC - content that is created, edited, viewed, and shared by users in Web 2.0
(Carrera, et al., 2008)). By using Groups and Pages, NTOs act as Facebook users. NTOs do not have to pay for such promotion, which gathers communities of costumers and influences travellers' booking decisions (Gretzel \& Yoo, 2008; Hennig-Thurau \& Walsh, 2003; O'Connor, 2008; Pan, et al., 2007). In this paper, the authors will examine how many NTOs in Europe have official presence on Facebook and determine the extent of use of basic Facebook user-generated content (Pages and Groups).

\section{Social media and tourism}

Social media are an emerging technology that is beginning to have a significant influence on how people communicate (Andrad \& Hilary, 2009). While there is a lack of a formal definition, "social media" can be generally understood as Internet-based applications that carry UGC, which encompasses media impressions created by users, typically informed by relevant experience, and archived or shared on-line for easy access by other impressionable consumers (Blackshaw, 2006). Blackshaw \& Nazzaro (2006) point out that social media exist in various forms and serve many purposes. UGC supported through social media are a mixture of fact and opinion, impression and sentiment, experiences, and even rumour (as cited in Graham, Faix, \& Hartman, 2009).

Social media have noticeably emerged on the Internet, underscoring changes that can significantly affect the travel and tourism industry (McGrath, 2008; Sigala, 2007). Hjalager (2010) even stresses that social media are gaining importance to such an extent that they are likely to entirely change (destination) marketing practices but the wider impacts of this massive technology push on the business of tourism, destinations and subsequent innovations, still has to be investigated.

Social media represent various forms of UGC such as blogs, virtual communities, wikis, social networks, collaborative tagging, and media files shared on sites (Xiang \& Gretzel, 2009) such as YouTube, Flickr, Veoh and Dailymotion. 
Buhalis (1998) stresses that consumers increasingly become familiar with the emergent ITs. The potential tourists have become more independent and sophisticated in using a wide range of tools to arrange for their trips (Buhalis \& Law, 2008). They expect to become active firms' partners for creating and consuming their personalized product and through social networks, customers can generate value for and from each other (Sigala, 2008).

Page (2009) points out that the first wave of Internet technology created an on-line travel community where tourism businesses were able to communicate with consumers through electronic media. This has been followed by a new wave of Web-based communities known as Web 2.0, also described as social media, where the on-line content is created by on-line users and made available to other users by means of Web 2.0 technology. The emergence of Web 2.0 brings together the concept of social networking/virtual communities and applies it to the tourism industry (Chung \& Buhalis, 2009). The importance of this technology is that it allows consumers to communicate about social themes such as holidays and travel.

Tourism organizations were some of the first to utilize the resources of the Internet, but we are seeing one area of significant Internet innovation in the widespread development of user generated content that would appear to have enormous potential for tourism organizations (Akehurst, 2009). As previously stated, NTOs are beginning to realize the importance of using the power of social media. Visit Britain formally launched their new social media initiative. Using software developed by Digital Visitor, Visit Britain enables visitors and residents to upload videos, still images, and make reviews on their own and others' contributions (Anon, 2009e). Mexico's tourism board will use social media, to combat negative publicity. The plan is to promote Mexico's tourist destinations via online communities, which will index content related to specific destination and facilitate user interaction via blogs and viral tools (Anon, 2009c). Still, NTOs have been very slow to respond to the global marketing opportunities presented by the rapid emergence of Web 2.0 applications and technologies (Hamill, 2009). O'Hare stresses that (2009) each NTO now has another tool to market their product to travellers. However, the adoption of Web 2.0 has been relatively slow compared to the pace of change of technology and the most tourism enterprises are at an early stage in applying Web 2.0 concepts to their businesses (Schegg, et al, 2008).

The Web has several popular social media websites that are designed to help social interaction between friends and build on-line communities. The examples of hugely popular general social media sites are: MySpace.com, Friendster.com, and Facebook.com (Pfister \& Tierney, 2009). Middleton (2009) underlines that social networking sites, such as Facebook and MySpace, take user control a stage further, allowing people to build their own on-line communities by linking their personal page to those of their friends. Beside communities based on off-line relationships, users can join groups linked by an experience. Facebook is different from other social media websites as most of Facebook users are met off-line and then added later (Ross, et al., 2009).

\section{Facebook - short history and characteristics}

Facebook is a website that was launched on February 4, 2004 and has become one of the most popular websites in history. Originally, it was available only to Harvard students, then it opened to students at other colleges and universities. In September 2006, it was opened to any user with an e-mail address, 13 years old or older. Their decision to open to nonstudents was followed by a huge surge in users (Alba \& Stay, 2008).

Facebook platform consists of five components launched in 2007. The platform consists of an HTML-based mark-up language called Facebook Mark-up Language (FBML), an application programming interface (API) for making representational state transfer (REST) calls to Facebook, an SQL-styled query language for interacting with Facebook called Facebook Query Language (FQL), a scripting language called Facebook JavaScript for enriching the user experience, and a set of client programming libraries. Generically, the tools that make up the Facebook platform are called the Facebook API. By releasing this 
platform, Facebook built an apparatus that allows developers to create external applications to empower Facebook users to interact with one another in new and exciting ways (Graham, 2008).

Alba and Stay (2008) stress that almost overnight, and for many reasons, Facebook went from "college social networking" to something professionals wanted to be involved in. They point up the primary reasons include the following: a huge user base; users are spending significant time on Facebook; user demographics are different from other social networking sites; Facebook has a history of introducing useful, enticing features for the users; and Facebook allows developers to create new applications that users can add into their own Profile.

Facebook currently has one site at the URL http://www.facebook.com that provides access for its users worldwide (LLC, 2007). Facebook is made up of many networks, each based around a workplace, region, secondary school or university.

Facebook enables its users to present themselves in an online profile (using text, pictures and video), gather "friends" who can post comments on each other's pages, and view each other's profiles. Facebook members can also join virtual groups based on common interests, see what classes they have in common, and learn each others' hobbies, interests, musical tastes, and romantic relationship status through the profiles (Ellison, Steinfield, \& Lampe, 2007).

Some of the main Facebook products (important for this paper) are:

Profile. The Profile page contains all the information about users that their friends and people in their networks can see.

Pages. Facebook Pages allows local businesses, brands, musicians, and all types of organizations to create a free presence on Facebook. Users can interact and affiliate as a fan of a business or organization in the same way they interact with other user profiles. Once a fan of a business on Facebook, users can share information about that business with their friends.

- Facebook Ads. Facebook Ads is an advertising system for businesses to create a presence on Facebook, spread information virally and to target advertising to the exact audiences they want. Facebook Ads consist of Facebook Pages and Social Ads.

- Inbox. The Inbox is where all users' messages are kept. All messages are visible only to the sender and recipients.

- Friends. The Friends page is the main source of finding information about Facebook friends. From the Friends page, users can find all of their Facebook friends update their friend details and quickly navigate to specific friends' profiles (Anon, 2009b).

- Status updates. Facebook has a microblogging feature called "status updates" (also referred to simply as "status") which allows users to post messages for all their friends to read. Facebook users can let other people know what they are doing by updating their status through the website, with an alert sent out to everyone on their friends list (Ramadge, 2007).

Among Facebook applications most used are: Photos (allows users to upload albums and photos), Groups (Profile user can join and create up to 200 groups. Groups can be based around shared interests, activities and other), Notes (display recently written notes in which Friends have been tagged and links to own notes), and among the features are: News Feed (aggregates the most interesting content that Friends are posting), Live Feed (shows you all the actions your friends are making in real-time), Share (button allows content to be shared on Facebook) and others (Anon, 2009b).

Groups can be important for individual and business users. With the Groups application, users can see Groups their friends have joined, as well as navigate to their own Groups, and create new Groups. Users can always search and browse for Groups to join. Groups can be based around shared interests, activities or 
anything else (Anon, 2009b). All these Pages, Groups and applications spread through the Facebook communities by being recommended by one user to their friends, examples of what is called viral marketing (Middleton, et al., 2009).

As mentioned above, Facebook can also be a good business tool. The main actions that a business can do with Facebook are: (1) keep track of employees; (2) stay up with the competition; (3) attract potential customers; (4) virally spread brand image; and (5) organize teams (Alba \& Stay, 2008). Still, the most significant use of Facebook is as a marketing tool. The beauty of using Facebook as a marketing tool comes from the endless ways in which a business can have free advertisement (Groups, Inbox, Applications, Notes etc.) (Anon, 2008).

\section{Methodology}

The purpose of the research was to identify how many NTOs in Europe have an official presence on Facebook and to examine the extent of use of Facebook Pages and Groups, as very important UGC. For the research, the authors used data on all 39 NTOs that are members of the European Travel Commission (ETC). Data collection and analysis was conducted in June and July 2009.
The first focus of the research was to discover the existence of an official presence of NTOs on Facebook. To gain those results, the authors used the internal Facebook search engine combined with the search engine provided by Google. The keywords used for search were country names, official NTO names, website URLs and e-mails. Because there were a vast number of search engine results, the authors had to double-check every Facebook Page or Group to confirm its authenticity. Authors examined only Pages and Groups that are clearly signed to be administrated by NTOs. Double-checking was also necessary because of the existence of many Pages, Groups with similar topics that are administrated by individuals and private companies.

The second scope of the research was to examine the extent of use of Facebook Pages and Groups. Using personal Facebook's Profiles, the authors observed the internal Facebook search engine results, the number of Page fans and members of Groups („friends“) and the use of Facebook tags, features or applications.

\section{Results}

Figure 1 summarizes the number of NTOs that do not have an official presence on Facebook and the number of official Pages, Groups and

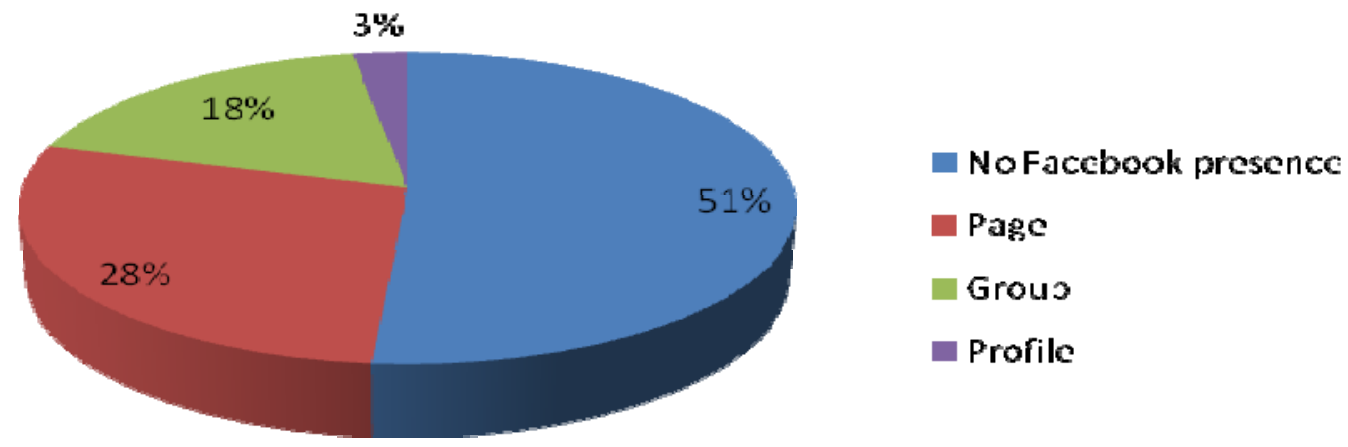

Figure 1. Percentage of NTOs on Facebook by type of official presence. 
The extent of use of basic Facebook user-generated content by the national tourism organizations in Europe.

Profiles. About half of NTOs do not have an official presence on Facebook. Almost onethird have Facebook Pages, and almost a fifth of them have a Group. The results show that the majority of NTOs in Europe has not realized the importance of user-generated content on Facebook. Of those with a Facebook presence, the majority have decided to use Pages instead of Groups. One NTO decided to use a Personal Profile that is against the terms of use, as Facebook does not allow creating a personal account for a company or organization. In addition, it looks artificial as it is being outside what people expect to see on Facebook.

The average number of "friends" on Facebook pages is 4919 . The largest number of "friends" was 32 402, and smallest was 45. The authors have to highlight that the number of friends is growing every day. Some Pages related to travel industry in European countries have more than 100000 "friends", much more than the official Pages of NTOs. The main reason is that those Pages are older than Pages of NTOs, as the first users of Facebook Pages create them.

Internal Facebook searches showed (for the name of country as main search keyword) that the average number is 432 results. Majority of searches had over 500 results. Among large number of search results, Facebook user can hardly recognize official Pages of NTOs. Therefore, the authors examined Pages and Groups pictures which help users in their searches. The majority of Pages used scenery pictures $(45 \%)$, followed by official logos of NTOs (36\%), and adopted logos (logos of NTOs in combination with official Facebook's logo) (9\%), and state flag pictures (9\%). In $86 \%$ of the cases, Groups used official logos of NTOs, and all other Groups (14\%) used state flag pictures. Facebook Pages are created for companies and non-profit organizations. Therefore, NTOs as business subjects should use logos rather than state flag pictures or country scenery pictures.

Pages and Groups offer many possibilities to promote contact and interact with friends and group members that gave permission for that kind of interaction. Usually, users are those who start membership in Groups and interaction with Pages. In that context, authors observed most used Facebook's features and applications.

Table 1 shows that Wall and Info are used by all observed NTOs Pages. Photos are used in most of Pages. More than half of them use Events. About half of NTO Pages use Discussion boards and Notes. More than a third of them use Links and Videos. Other features and applications (in form of customized tabs) are used in almost a fifth of Pages.

\section{Table 1. The extent of the use of Facebook Page features and applications}

\begin{tabular}{|l|l|}
\hline Feature or application & $\%$ \\
\hline Wall & 100 \\
\hline Info & 100 \\
\hline Photos & 82 \\
\hline Events & 55 \\
\hline Discussion board & 45 \\
\hline Notes & 45 \\
\hline Links & 36 \\
\hline Video & 36 \\
\hline Other & 18 \\
\hline
\end{tabular}

Groups have limited numbers of features and applications. Most used are Links (71\%), followed by Discussion board and Wall with the same percentage $(57 \%)$. Video was used in $29 \%$ of Groups, while Notes and Events in just $14 \%$ of the observed Groups.

\section{Conclusion}

Facebook is the most popular social medium in Europe and in the world. Every NTO with limited resources will have to prioritize different areas of online marketing, including social media based on their current impact, as well as their longer-term potential (Anon, 2009d). NTOs in Europe still do not have significant presence on Facebook. About half of NTOs do not have an official presence on Facebook, almost one-third has Facebook Pages, and almost a fifth of them have a Group. The fact that only 19 NTOs use Facebook shows that only limited progress has been made. Most of 
NTOs have been slow to respond to the marketing opportunities brought by currently most popular social networking website in the world.

The average Facebook user is confronted with several obstacles in finding official NTO Pages and Groups. The main obstacles are the large number of search results on search queries and the use of sceneries and flags as Pages and Group pictures that do not match the type of the organization they should represent.

The observation of those NTOs that use Facebook showed that they do not use all advantages offered by this form of usergenerated content. The most used Facebook features are those that are generated by the fans of Pages and members of Groups. This is also important, but the NTOs have to open more discussion, create applications, and upload photo albums and promotional videos.

Facebook community is in constant growth (Ostrow, 2009) and will have more and more influence. A main task of an NTO is to promote its country as a tourism destination. Therefore, the authors recommend that NTOs should consider using Facebook, as a potentially effective marketing strategy for the next couple of years. This paper encourages NTOs in Europe to create their own presence on Facebook, and to expand the use of Facebook Page and Groups features and applications, as an effective UGC.

\section{Acknowledgements}

The research was supported by the Ministry of Science of the Republic of Serbia (project no. 146019)

\section{References}

Akehurst, G. (2009) User Generated Content: the Use of Blogs for Tourism Organisations and Tourism Consumers. Service Business 3(1), pp. 51-61.

Alba, J., \& Stay, J. (2008) I'm on Facebook-now what??? How to get personal, business, and professional value from Facebook. Silicon Valley: Cupertino, CA : HappyAbout.info

Andrad, C. S., \& Hilary, M. (2009) Digital Imaging Treck: A Practical Model for
Managing the Demand of the Digitally Enabled Traveller. In E. Szewczak (ed.) (2009) Selected readings on the human side of information technology. Hershey, PA: Information Science Reference, pp. 475-498

Anon (2008) The Facebook Marketing Toolbox: 100 Tools and Tips to Tap the Facebook Customer Base. URL: http://www.insidecrm.com/features/faceb ook-marketing-toolbox-012308/ (Accessed on 30.07.2009)

Anon (2009a) Social Netwrking and UGC. URL: http://www.newmediatrendwatch.com/re gional-overview/103-europe?start=7 (Accessed on 29.07.2009)

Anon (2009b) Product Overview. URL: http://www.facebook.com/press/product. php\#/press/product.php (Accessed on 28.07.2009)

Anon (2009c) Mexico Tourism Board to Use Social Media to Combat Negative Publicity. URL: http://www.world-tourismnews.eu/news/mexico-tourism-board-touse-social-media-to-combat-negativepublicity/ (Accessed on 18.11.2009)

Anon (2009d) Social Media Marketing Best Practices for DMOs. URL: http://www.milesmedia.com/ireport/imag es/pdf/SocialMediaCommentary_MM_Ju ne2009.pdf (Accessed on 13.10.2009)

Anon (2009e) Using UGC to Attract Visitors who leads?. URL:

http://tourisminternetmarketing.com/featu red/using-ugc-to-attract-visitors-wholeads/\#more-175 (Accessed on 21.10.2009)

Blackshaw, P. (2006) The ConsumerGenerated Surveillance Culture. URL: http://www.clickz.com/showPage.html?p age=3576076 (Accessed on 01.08.2009)

Buhalis, D. (1998) Strategic Use of Information Technologies in the Tourism Industry. Tourism Management 19(5), pp. 409421

Buhalis, D., \& Law, R. (2008) Progress in information technology and tourism management: 20 years on and 10 years after the Internet The state of eTourism research. Tourism Management 29(4), pp. $609-623$ 
The extent of use of basic Facebook user-generated content by the national tourism organizations in Europe.

Carrera P., Chiu Ch., Pratipwattanawong P., Chienwattanasuk S., Ahmad S. F. S., \& Jamie, M. (2008) My Space, My Friends, My Customers. In P. O'Connor, W. Höpken \& U. Gretzel (eds.) (2008) Information and communication technologies in tourism 2008: proceedings of the international conference in Innsbruck, Austria 2008. Wien; New York: Springer, pp. 94-105

Chung, J. \& Buhalis, D. (2009) Virtual Travel Community: Bridging Travellers and Locals. In Sharda, N. (ed). Tourism Informatics: Visual Travel Recommender Systems, Social Communities, and User Interface Design. Hershey: Information Science Reference, pp. 130-144

Chung, J. Y., \& Buhalis, D. (2008) Information Needs in Online social Networks. Information Technology \& Tourism 10(4), pp. 267-281

Ellison, N., Steinfield, C., \& Lampe, C. (2007) The Benefits of Facebook Friends: Social Capital and College Students' Use of Online Social Network Sites. Journal of Computer Mediated Communication 12(4), URL:

http://jcmc.indiana.edu/vol12/issue4/ellis on.html (Accessed on 19.06.2009)

Graham, J., Faix, A., \& Hartman, L. (2009) Crashing the Facebook party. Library Review 58(3), pp. 228-236

Graham, W. (2008). Facebook API Developers Guide. Berkeley: Apress.

Gretzel, U. and K. Yoo (2008) Use and Impact of Online Travel Reviews. Information and Communication Technologies in Tourism, pp. 35-46.

Hamill, J. (2002) National DMOs and Web 2.0: The State-of-Play. URL:

http://www.tourism2-0.co.uk/profiles /blog/show?id=2021287\%3ABlogPost\%3 A1691 (Accessed on 2.08.2009)

Hjalager, A. (2010) A Review of Innovation Research in Tourism. Tourism Management 31(1), pp. 1-12

Hennig-Thurau, T. and G. Walsh (2003) Electronic Word-of-Mouth: Motives for and Consequences of Reading Customer Articulations on the Internet. International Journal of Electronic Commerce 8(2), pp. 51-74.
Illum, S. F., Ivanov, S., \& Liang, Y. (2010) Using Virtual Communities in Tourism Research. Tourism Management, 31(3), pp. 335-340

LLC, B. (2007) Facebook Fanatic: Explode Your Popularity, Secure Your Privacy and Buzz Your Band on Facebook. Memphis: Bottletree Books Llc.

McEntegart, J. (2009) Facebook Hits 250 Million Members. URL:

http://www.tomsguide.com/us/FacebookMembers-250-Million, news-4241.html (Accessed on 30.07.2009)

McGrath, M. (2008) Employing 'Social Network Analysis' to Influence

Tourism Events Decision-Making: A Pilot Study. In P. O'Connor, W. Höpken \& U. Gretzel (eds.) (2008) Information and communication technologies in tourism 2008: proceedings of the international conference in Innsbruck, Austria 2008. Wien; New York: Springer, pp. 556-567

Middleton, V. T. C., Fyall, A., Morgan, M., \& Ranchhod, A. (2009) Marketing in Travel and Tourism. Oxford: ButterworthHeinemann

O'Connor, P. (2008) User-Generated Content and Travel: A Case Study on Tripadvisor.Com. In P. O'Connor, W. Höpken \& U. Gretzel (eds.) (2008) Information and communication technologies in tourism 2008: proceedings of the international conference in Innsbruck, Austria 2008. Wien; New York: Springer, pp. 47-58

O'Hare, P. (2009) Web 2.0 and European city based DMOs. URL: http://www.tourism2$0 . c o . u k / p r o f i l e s / b l o g s / w e b-20-a n d-$ european-city-based (Accessed on 10.09.2009)

Ostrow, A. (2009) Twitter and Facebook Post Huge Growth Numbers in March. URL: http://mashable.com/2009/04/06/twitterand-facebook-post-huge-growthnumbers-in-march/ (Accessed on 20.11.2009)

Page, S. J. (2009) Tourism Management: Managing for Change (3 ed.). Oxford: Butterworth-Heinemann

Pan, B., T. MacLaurin, et al. (2007) Travel Blogs and the Implications for 
Destination Marketing. Journal of Travel Research 46(1), pp. 35 - 45

Pfister, R. E., \& Tierney, P. T. (2009) Recreation, event and tourism businesses: start-up and sustainable operations. Champaign, IL: Human Kinetics

Ramadge, A. (2007) Facebook is... reconsidering the word 'is'. URL: http://www.news.com.au/technology/face book-is-reconsidering-the-word-is/storye6frfro0-1111114967059 (Accessed on 10.09.2009)

Ross, C., Orr, E., Sisic, M., Arseneault, J., Simmering, M., \& Orr, R. (2009) Personality and motivations associated with Facebook use. Computers in Human Behavior 25(2), pp. 578-586

Schegg, R., Liebrich, A., Scaglione, M., \&Ahmad, S (2008) An Exploratory Field Study of Web 2.0 in Tourism. In P. O'Connor, W. Höpken \& U. Gretzel (eds.) (2008) Information and communication technologies in tourism 2008: proceedings of the international conference in Innsbruck, Austria 2008. Wien; New York: Springer, pp. 152-163

Sigala, M. (2007) Web 2.0 in the Tourism Industry: a New Tourism Generation and New e-Business models. URL: http://www.traveldailynews.com/makeof. asp?sstr=Web\%202.0\&central_id=1439

$$
\text { \&permanent_id=31 }
$$$$
\text { 17.11.2009) }
$$

(Accessed

Sigala, M. (2008) Developing and Implementing an eCRM 2.0 Strategy: Usage and Readiness of Greek Tourism Firms. In P. O'Connor, W. Höpken \& U. Gretzel (eds.) (2008) Information and communication technologies in tourism 2008: proceedings of the international conference in Innsbruck, Austria 2008. Wien; New York: Springer, pp. 463-474

Wang, Y., \& Fesenmaier, D. (2003) Assessing Motivation of Contribution in Online Communities: An empirical investigation of an online travel community. Electronic Markets 13(1), pp. 33-45

Wang, Y., Yu, Q., \& Fesenmaier, D. (2002) Defining the Virtual Tourist Community: Implications for Tourism Marketing. Tourism Management 23(4), pp. 407-417

White, L. (2009) Facebook, Friends and Photos: A Snapshot into Social Networking for Generating Travel Ideas. In Sharda, N. (ed). Tourism Informatics: Visual Travel Recommender Systems, Social Communities, and User Interface Design. Hershey: Information Science Reference, pp. 115-129

Xiang, Z., \& Gretzel, U. (2009) Role of Social Media in Online Travel Information Search. Tourism Management 31(2), pp. 179-188. 